\title{
Calcium and phosphorus requirements of the very young turkey as determined by response surface analysis
}

\author{
BY ALAN M. SANDERS ${ }^{1}$, HARDY M. EDWARDS JR ${ }^{1}$ \\ AND GEORGE N. ROWLAND III' \\ Departments of 'Poultry Science and ${ }^{2}$ Avian Medicine, The University of Georgia, Athens, \\ GA 30602, USA
}

(Received 12 February 1991-Accepted 5 July 199I)

\begin{abstract}
The first experiment was a central composite rotatable design with calculated calcium levels of $6 \cdot 2,7 \cdot 0$, $9.0,11 \cdot 0$, and $11.8 \mathrm{~g} / \mathrm{kg}$ diet and total phosphorus levels of $5 \cdot 2,6.0,8.0,10.0$, and $10.8 \mathrm{~g} / \mathrm{kg}$ diet $(2.8 \mathrm{~g}$ phytin-P/kg by analysis). This design involved three replicates for each rotatable point and fifteen replicates of the central point. The second experiment was a $4 \times 4$ factorial design with calculated $\mathrm{Ca}$ levels of 8.0, 10.0, 12.0, and $14.0 \mathrm{~g} / \mathrm{kg}$ diet and calculated total $P$ levels of $7 \cdot 0,9 \cdot 0,11 \cdot 0$, and $13.0 \mathrm{~g} / \mathrm{kg}$ diet $(2.5 \mathrm{~g}$ phytin-P/ $\mathrm{kg}$ by analysis). There were four replicates for each treatment. In both $16 \mathrm{~d}$ experiments maize-soya-bean diets were used and each replicate consisted of one pen containing 10-d-old broad-breasted, white tom turkeys. The $\mathrm{Ca}$ and total $\mathrm{P}$ requirements for optimum growth were estimated to be 12.5 and $10.0 \mathrm{~g} / \mathrm{kg}$ diet respectively. Bone ash was adequate at these levels of $\mathrm{Ca}$ and total $\mathrm{P}$, but maximum bone ash was not achieved until much higher levels of $\mathrm{Ca}$ and total $\mathrm{P}$ were employed. At the required levels of $\mathrm{Ca}$ and total $\mathrm{P}$ for growth the incidences of $\mathrm{Ca}$ - and $\mathrm{P}$-deficiency rickets were very low. There were no treatment effects on feed efficiency. Increasing dietary Ca decreased the incidence of the Ca-deficiency lesion. There was a quadratic response due to dietary total $P$ on both P-deficiency rickets and plasma dialysable $P$; intermediate levels of dietary $P$ resulted in low incidence of the P-deficiency lesion and high levels of plasma dialysable $P$. There was a strong negative correlation between the incidence of $\mathrm{P}$-deficiency rickets and plasma dialysable $\mathrm{P}$. Percentage retention was very low at high levels of dietary $P$ and low levels of $C a$ which corresponded with slightly higher $P$-deficiency rickets and low plasma dialysable $P$. No such obvious relationships existed between $C a$ retention, incidence of Ca-deficiency rickets, and plasma $\mathrm{Ca}$. The incidence of tibial dyschondroplasia was very low in the present study. There were pronounced dietary treatment effects on phytin-P retention; at $14 \mathrm{~d}$ percentage phytin-P retention treatment means ranged from 18 to 46 in Expt 1 and from 0 to 40 in Expt 2 with the highest retention of phytin-P at low levels at both $C a$ and total $P$.
\end{abstract}

Calcium: Phosphorus: Phytin-phosphorus retention: Rickets: Tibial dyschondroplasia: Turkey

There have been numerous studies concerning the calcium and phosphorus requirements in the very young turkey for over 50 years (Mussehl \& Ackerson 1935). The latest study that examined both the $\mathrm{Ca}$ and $\mathrm{P}$ requirement in the turkey was conducted more than 13 years ago (Choi \& Harms, 1977). Further study in this area is warranted simply on the grounds that the modern, faster-growing turkey may respond differently from the turkey of 13 years ago. Almost all studies to date have dealt only with growth, feed efficiency, and bone ash as the response criteria measured. The gross, microscopic, and radiographic lesions of both Ca- and P-deficiency-type rickets have been well documented in the broiler (Long et al. $1984 a, b, c)$, but the effects of various levels of dietary $\mathrm{Ca}$ and $\mathrm{P}$ on the incidence of these lesions have not been investigated. Edwards \& Veltmann (1983) reported that a narrow $\mathrm{Ca}$ :total $\mathrm{P}$ ratio will induce tibial dyschondroplasia in young broilers; no work to date, 
however, has been reported that examined the possible relationship between $\mathrm{Ca}, \mathrm{P}$, and tibial dyschondroplasia in the turkey. Edwards (1983) and Edwards \& Veltmann (1983) have reported that the percentage retention of $\mathrm{Ca}, \mathrm{P}$, and phytin- $\mathrm{P}$ of the broiler and commercial layer can vary tremendously with changing levels of dietary $\mathrm{Ca}$ and $\mathrm{P}$. Such an examination of the retention of these minerals has not been examined in the turkey.

The purpose of the present study was to determine the $\mathrm{Ca}$ and total $\mathrm{P}$ requirements of the modern broad-breasted white tom turkey for performance and bone ash. Further, the effects of graded levels of dietary $\mathrm{Ca}$ and total $\mathrm{P}$ on the incidence of $\mathrm{Ca}$ - and P-deficiencytype rickets, the incidence of tibial dyschondroplasia, plasma $\mathrm{Ca}$, plasma dialysable $\mathrm{P}$, and the retention of $\mathrm{Ca}, \mathrm{P}$, and phytin- $\mathrm{P}$ will be examined. In addition, the relationships between the various response criteria will be addressed, as well as how they relate to the Ca and total $P$ requirements.

\section{FXPERIMENTAL PROCEDURES}

Both experiments were conducted identically except as noted. Nicholas Large White tom turkeys were obtained from a commercial hatchery, identified with wing bands, and placed 10 per pen in electrically heated Petersime Battery brooders equipped with wire-mesh floors. The batteries were kept in a room in which the temperature was maintained at $22^{\circ}$. Light was provided $24 \mathrm{~h} / \mathrm{d}$ by fluorescent lights and sunlight was present during daylight hours from large windows on the east side of the room. The fluorescent lights used in the battery were General Electric, F15T8-CW, with no diffusers, providing $3.4 \%$ of the wattage in the u.v. range $(260-400 \mathrm{~nm})$. Feed and water were provided $a d$ lib.

Body-weight was measured by pen on days 7 and 16. Feed consumption was recorded for determination of feed efficiency on day 16 . Each diet contained $1 \mathrm{~g}$ chromic oxide $/ \mathrm{kg}$ (Table 1 ) in order to determine the retention of $\mathrm{Ca}, \mathrm{P}$, and phytin-P. Dried feed and excreta samples (collected on days 7 and 14) were analysed for $\mathrm{Cr}_{2} \mathrm{O}_{3}$ (Brisson, 1956), Ca (Hill, 1955), P (O'Neil \& Webb, 1970) and phytin-P (Common, 1940), and the percentage retention of $\mathrm{Ca}, \mathrm{P}$ and phytin-P was calculated. In Expt 2, but not Expt 1, blood samples were taken by cardiac puncture with heparinized syringes from one randomly chosen bird from each pen. The plasma samples were then analysed for $\mathrm{Ca}$ (Technicon Instruments Corporation, 1969) and dialysable P (Technicon Instruments Corporation, 1970). On day 16, after the birds were weighed, they were all killed, mixed to obscure dietary treatment, and scored grossly for the incidence of Ca-deficiency-type rickets (Long et al. 1984b), Pdeficiency-type rickets (Long et al. 1984a) and tibial dyschondroplasia (Edwards \& Veltmann, 1983) by making a sagittal cut at the proximal end of the right tibia (Plate 1). Birds in which the growth plate band proliferating prehypertrophied zone was noticeably lengthened were classified as having $\mathrm{Ca}$-deficiency rickets. Birds which had a normal proliferating prehypertrophied zone and a lengthened metaphyseal primary spongiosa were classified as having P-deficiency rickets. Birds in which the avascular zone of hypertrophied cells was focally lengthened were classified as having tibial dyschondroplasia. The left tibias were removed for bone ash determination on the fat-free dry bone (Association of Official Agricultural Chemists, 1955).

The basal diets for both experiments were practical maize-soya-bean-type diets (Table 1) formulated to meet or exceed all National Research Council (1984) nutrient requirements with the exception of $\mathrm{Ca}$ and $\mathrm{P}$. The various levels of $\mathrm{Ca}$ and $\mathrm{P}$ used in both experiments were achieved by the substitution of limestone and dicalcium phosphate into the diet at the expense of maize. Expt 1 was designed according to Box \& Wilson's (1951) central composite rotatable design. Dietary levels of $\mathrm{Ca}$ and $\mathrm{P}$ were the two independent variables. The dietary levels of $\mathrm{Ca}$ in Expt 1 were $6 \cdot 2,7 \cdot 0,9 \cdot 0,11 \cdot 0$, and $11.8 \mathrm{~g} / \mathrm{kg}$. The 
Table 1. Composition of basal diets $(\mathrm{g} / \mathrm{kg})$

\begin{tabular}{|c|c|c|}
\hline Ingredients & Expt 1 & Expt 2 \\
\hline Maize* & 444 & 437 \\
\hline Soyabean meal, dehulled & 500 & 500 \\
\hline Poultry fat & 40 & 40 \\
\hline Dicalcium phosphate & - & $5 \cdot 0$ \\
\hline Vitamin mixture ${ }^{\dagger}$ & 2.5 & $2 \cdot 5$ \\
\hline $\mathrm{NaH}_{2} \mathrm{PO}_{4} \cdot \mathrm{H}_{2} \mathrm{O}$ & $4 \cdot 2$ & $7 \cdot 7$ \\
\hline DL-methionine & $2 \cdot 0$ & $2 \cdot 0$ \\
\hline L-lysine hydrochloride & $1 \cdot 0$ & $1 \cdot 0$ \\
\hline Selenium concentrate & $0-5$ & 0.5 \\
\hline Sodium chloride & $3 \cdot 5$ & $2 \cdot 0$ \\
\hline Trace mineral mixture $\S$ & $1 \cdot 0$ & $1 \cdot 0$ \\
\hline Chromic oxide & $1 \cdot 0$ & $1 \cdot 0$ \\
\hline
\end{tabular}

* Various levels of calcium and phosphorus were achieved by substitution of dicalcium phosphate and limestone at the expense of maize.

† Vitamin mixture provides (mg/kg diet): vitamin A (as all-trans-retinyl acetate) 1892, vitamin E (all DL- $\alpha$ tocopheryl acetate) 11 , menadione (as menadione sodium bisulphite) $1 \cdot 1$, cholecalciferol $27.5 \mu \mathrm{g}$, riboflavin 4.4 , calcium pantothenate 12 , nicotinic acid 44 , choline chloride 220 , vitamin $B_{12} 9 \mu \mathrm{g}$, vitamin $B_{8} 3 \cdot 0$, thiamin (as thiamin mononitrate) $2 \cdot 2$, folic acid 3 , biotin $0 \cdot 3$, and ethoxyquin 125 .

$\ddagger 0.2 \mathrm{~g}$ Se from sodium selenite/ $\mathrm{kg}$ in a calcium carbonate carrier.

$\S$ Trace mineral mixture provides $\mathrm{mg} / \mathrm{kg}$ diet: manganese 120 , zinc 100 , iron 60 , copper 10 , iodine $2 \cdot 10$, Ca $150(\min ), 180(\max )$.

dietary levels of total $P$ were $5 \cdot 2,6 \cdot 0,8 \cdot 0,10 \cdot 0$, and $10 \cdot 8 \mathrm{~g} / \mathrm{kg}$ (phytin-P was $2 \cdot 8 \mathrm{~g} / \mathrm{kg}$ by analysis). There were three replicates for each rotatable point and fifteen replicates for the central point, with each pen constituting a replicate for a total of thirty-nine pens and 390 birds. Expt 2 was an incomplete $4 \times 4$ factorial design. The Ca levels were $8 \cdot 0,10 \cdot 0,12 \cdot 0$, and $14.0 \mathrm{~g} / \mathrm{kg}$ diet. The total $\mathrm{P}$ levels were $7 \cdot 0,9 \cdot 0,11.0$ and $13.0 \mathrm{~g} / \mathrm{kg}$ diet (phytin-P was $2.5 \mathrm{~g} / \mathrm{kg}$ by analysis). An incomplete factorial design was utilized because the diet with $8.0 \mathrm{~g}$ $\mathrm{Ca}$ and $13.0 \mathrm{~g} \mathrm{P} / \mathrm{kg}$ was impossible to formulate with the ingredients used; this treatment was, therefore, omitted. There were a total of fifteen treatments with four replicates per treatment, each pen constituting a replicate, for a total of sixty pens and 600 birds.

The data were analysed by multiple-regression analysis and regression equations were derived. Response surfaces were generated from these equations for the various responses measured. Also, correlation coefficients between several of the response criteria were determined within each experiment.

\section{RESULTS}

Dietary $\mathrm{Ca}$ level had very little effect on growth in either experiment (Tables 2 and 3; Figs 1 and 2 (A and B)). There was, however, a consistent quadratic growth response due to dietary total $P$ in both experiments at both 7 and $16 \mathrm{~d}$; total $P$ levels above $10.6 \mathrm{~g} / \mathrm{kg}$ diet resulted in depressed growth. The regression analysis indicates that $16.7 \mathrm{~g} \mathrm{Ca} / \mathrm{kg}$ and $10.6 \mathrm{~g}$ total $\mathrm{P} / \mathrm{kg}$ are the requirements for optimum $16 \mathrm{~d}$ growth in Expt 1 and $12.4 \mathrm{~g} \mathrm{Ca} / \mathrm{kg}$ and $10.2 \mathrm{~g}$ total $\mathrm{P} / \mathrm{kg}$ are the requirements for optimum $16 \mathrm{~d}$ growth in Expt 2 . There were no significant treatment effects in either experiment on feed efficiency (Tables 2 and 3; Figs 1 and $2(\mathrm{~F})$ ).

There was a significant, although not readily obvious, quadratic bone ash response due to $\mathrm{Ca}$ in both experiments (Tables 2 and 3; Figs 1 and 2(E)). There was also a quadratic 
Table 2. Expt 1. The effects of various dietary calcium and phosphorus levels on body-weight, gain:feed, rickets, and bone ash of very young turkeys

\begin{tabular}{|c|c|c|c|c|c|c|c|}
\hline \multicolumn{2}{|c|}{ Dietary treatments $(\mathrm{g} / \mathrm{kg})$} & \multicolumn{2}{|c|}{ Body-wt (g) } & \multicolumn{3}{|c|}{ Rickets incidence $(\%)$} & \multirow[b]{2}{*}{ Bone ash $(\mathrm{g} / \mathrm{kg})$} \\
\hline $\mathrm{Ca}$ & $\mathrm{P} \ddagger$ & $7 \mathrm{~d}$ & $16 \mathrm{~d}$ & Gain: feed & $\mathrm{Ca} \$$ & $P \|$ & \\
\hline $9 \cdot 0$ & $5 \cdot 2$ & 113 & 312 & 0.706 & 0 & 94 & 270 \\
\hline $7 \cdot 0$ & $6 \cdot 0$ & 143 & 389 & 0.784 & 42 & 10 & 350 \\
\hline 11.0 & $6 \cdot 0$ & 141 & 375 & 0.799 & 25 & 56 & 320 \\
\hline $6 \cdot 2$ & $8 \cdot 0$ & 142 & 385 & 0.744 & 64 & 13 & 370 \\
\hline $9 \cdot 0$ & $8 \cdot 0$ & 150 & 416 & 0.789 & 9 & 1 & 410 \\
\hline 11.8 & $8 \cdot 0$ & 150 & 419 & 0.796 & 15 & 4 & 420 \\
\hline $7 \cdot 0$ & $10 \cdot 0$ & 148 & 404 & 0.768 & 43 & 0 & 390 \\
\hline $11 \cdot 0$ & $10 \cdot 0$ & 145 & 427 & 0.821 & 3 & 0 & 420 \\
\hline $9 \cdot 0$ & $10 \cdot 8$ & 139 & 407 & 0.793 & 15 & 8 & 410 \\
\hline Mean & & 146 & 400 & 0.781 & 19 & 15 & 380 \\
\hline SEM & & 4 & 11 & 0.021 & 7 & 7 & 10 \\
\hline \multicolumn{8}{|c|}{ Regression analysis model } \\
\hline Interce & & $24 \cdot 0$ & $16 \cdot 0$ & $0.619^{*}$ & $327 \cdot 7^{*}$ & $233 \cdot 3^{*}$ & $-17 \cdot 6^{*}$ \\
\hline $\mathrm{Ca}$ & & $63 \cdot 7$ & $-40 \cdot 2$ & -0.064 & $-723 \cdot 3^{*}$ & $236 \cdot 0$ & $3 \cdot 6$ \\
\hline $\mathrm{P}$ & & $231 \cdot 6^{*}$ & $878 \cdot 4^{*}$ & 0.316 & $104 \cdot 3$ & $-752 \cdot 3^{*}$ & $1160^{*}$ \\
\hline $\mathrm{Ca} \times \mathrm{C}$ & & $-30 \cdot 5$ & $-62 \cdot 3$ & -0.020 & $422 \cdot 7^{*}$ & 8.0 & $-18 \cdot 3^{*}$ \\
\hline $\mathrm{Ca} \times \mathrm{P}$ & & $-6 \cdot 3$ & $235 \cdot 4$ & 0.235 & $-145 \cdot 8$ & $-286 \cdot 9 *$ & $41 \cdot 7^{*}$ \\
\hline $\mathrm{P} \times \mathrm{P}$ & & $-136 \cdot 8^{*}$ & $-602 \cdot 2^{*}$ & -0.279 & $17 \cdot 1$ & $557 \cdot 7^{*}$ & $-82 \cdot 5^{*}$ \\
\hline$R^{2}$ & & 0.35 & 0.71 & 0.28 & 0.72 & 0.82 & 0.94 \\
\hline Maxim & response & $9 \cdot 6$ & $16 \cdot 7$ & -11.6 & 12.5 & $7 \cdot 4$ & $13 \cdot 0$ \\
\hline Maxim & esponse $\uparrow$ & $8 \cdot 2$ & $10 \cdot 6$ & 0.8 & $22 \cdot 6$ & $8 \cdot 6$ & $10 \cdot 2$ \\
\hline Predict & imum & 150 & 446 & $0.668 \dagger$ & -5 & $-5 \dagger$ & 44 \\
\hline
\end{tabular}

* The coefficient was significantly less than zero $(P \leqslant 0.05)$.

$\dagger$ The solution was a saddle point; all others were a maximum or minimum.

\$ Phytin-P was analysed to be $2.8 \mathrm{~g} / \mathrm{kg}$ diet.

$\S$ Incidence of Ca-deficiency-type rickets.

$\|$ Incidence of P-deficiency-type rickets.

T $\mathrm{g} / \mathrm{kg}$ diet.

bone ash response due to total $\mathrm{P}$; this quadratic response due to dietary $\mathrm{P}$ was very pronounced in both experiments. In addition there was a $\mathrm{Ca} \times$ total $\mathrm{P}$ interaction in both experiments on bone ash; at low levels of either element high levels of the other element resulted in decreased bone ash. At high levels of both elements, however, no such detrimental effects were observed. For maximum bone ash in Expt 1 the regression analysis indicates that $13.0 \mathrm{~g} \mathrm{Ca} / \mathrm{kg}$ and $10.2 \mathrm{~g}$ total $\mathrm{P} / \mathrm{kg}$ were required; in Expt $2,13.8 \mathrm{~g} \mathrm{Ca} / \mathrm{kg}$ and $11.7 \mathrm{~g}$ total $\mathrm{P} / \mathrm{kg}$ were required.

There was clearly a linear relationship between dietary $\mathrm{Ca}$ and $\mathrm{Ca}$-deficiency rickets in both experiments with increasing levels of $\mathrm{Ca}$ decreasing the incidence of the $\mathrm{Ca}$-deficiency lesion (Tables 2 and 3; Figs 1 and 2(C)). There was a small but significant quadratic Cadeficiency rickets response due to dietary $\mathrm{Ca}$ in Expt 1, but not in Expt 2. For minimum Ca-deficiency rickets in Expt 1 a dietary level of $12.5 \mathrm{~g} \mathrm{Ca} / \mathrm{kg}$ was required while in Expt 2 a dietary Ca level of $14.7 \mathrm{~g} / \mathrm{kg}$ was required.

There was a quadratic response due to total dietary $\mathrm{P}$ on the incidence of P-deficiency rickets in both experiments with the incidence of P-deficiency rickets decreasing to a point, then increasing with the highest levels of dietary total $\mathbf{P}$ (Tables 2 and 3); Figs. 1 and 2(D)). There was a $\mathrm{Ca} \times$ total $\mathrm{P}$ interaction on the $\mathrm{P}$ deficiency response; high levels of dietary $\mathrm{Ca}$ increased the incidence of P-deficiency rickets at low levels of total P. In Expt 1 the levels 
Table 3. Expt 2. The effects of various dietary calcium and phosphorus levels on body weight, gain:feed, rickets, and bone ash of very young turkeys

\begin{tabular}{|c|c|c|c|c|c|c|c|}
\hline \multicolumn{2}{|c|}{ Dietary treatments $(\mathrm{g} / \mathrm{kg})$} & \multicolumn{2}{|c|}{ Body-wt (g) } & \multirow[b]{2}{*}{ Gain: feed } & \multicolumn{2}{|c|}{ Rickets incidence $(\%)$} & \multirow[b]{2}{*}{ Bone ash $(\mathrm{g} / \mathrm{kg})$} \\
\hline $\mathrm{Ca}$ & $\mathrm{P}_{+}^{+}$ & $7 \mathrm{~d}$ & $16 \mathrm{~d}$ & & $\mathrm{Ca} \S$ & $\mathbf{P} \|$ & \\
\hline 8 & 7 & 142 & 371 & 0.757 & 35 & 22 & 580 \\
\hline 10 & 7 & 144 & 386 & 0.758 & 11 & 37 & 380 \\
\hline 12 & 7 & 150 & 403 & 0.780 & 13 & 67 & 370 \\
\hline 14 & 7 & 140 & 375 & 0.788 & 0 & 98 & 350 \\
\hline 8 & 9 & 154 & 410 & 0.747 & 41 & 11 & 410 \\
\hline 10 & 9 & 152 & 409 & 0.769 & 21 & 5 & 410 \\
\hline 12 & 9 & 152 & 389 & 0.735 & 5 & 3 & 420 \\
\hline 14 & 9 & 151 & 418 & 0.797 & 8 & 8 & 420 \\
\hline 8 & 11 & 140 & 367 & 0.722 & 50 & 8 & 390 \\
\hline 10 & 11 & 149 & 408 & 0.762 & 38 & 3 & 410 \\
\hline 12 & 11 & 151 & 409 & 0.758 & 30 & 3 & 430 \\
\hline 14 & 11 & 150 & 406 & 0.755 & 15 & 5 & 430 \\
\hline 10 & 13 & 147 & 397 & 0.755 & 41 & 9 & 410 \\
\hline 12 & 13 & 146 & 381 & 0.753 & 11 & 8 & 420 \\
\hline 14 & 13 & 153 & 400 & 0.774 & 24 & 8 & 420 \\
\hline Mean & & 148 & 395 & 0.760 & 23 & 19 & 400 \\
\hline SEM & & 4 & 14 & $0 \cdot 018$ & 9 & 7 & 10 \\
\hline \multicolumn{8}{|c|}{ Regression analysis model } \\
\hline Intercep & & $83 \cdot 4^{*}$ & $107 \cdot 1$ & $0 \cdot 816^{*}$ & $118 \cdot 9$ & $255 \cdot 3^{*}$ & $7 \cdot 7$ \\
\hline $\mathrm{Ca}$ & & $50 \cdot 5$ & $205 \cdot 7$ & 0.039 & $-244 \cdot 8^{*}$ & $49 \cdot 8$ & $6 \cdot 5$ \\
\hline $\mathrm{P}$ & & $71 \cdot 4$ & $347 \cdot 2^{*}$ & $-0 \cdot 197$ & $102 \cdot 2$ & $-531 \cdot 2^{*}$ & $53 \cdot 0^{*}$ \\
\hline $\mathrm{Ca} \times \mathrm{Ca}$ & & $-39 \cdot 1$ & $-114 \cdot 1$ & 0.016 & $94 \cdot 6$ & $106.2^{*}$ & $-11 \cdot 3^{*}$ \\
\hline $\mathrm{Ca} \times \mathrm{P}$ & & $44 \cdot 8^{*}$ & $76 \cdot 1$ & $-0 \cdot 021$ & $-20 \cdot 9$ & $-226 \cdot 5^{*}$ & $21 \cdot 1^{*}$ \\
\hline $\mathbf{P} \times \mathbf{P}$ & & $-60 \cdot 2^{*}$ & $-216 \cdot 4^{*}$ & 0.096 & $-22 \cdot 0$ & $382 \cdot 1^{*}$ & $-35 \cdot 0^{*}$ \\
\hline$R^{2}$ & & 0.22 & 0.15 & 0.17 & 0.45 & 0.81 & 0.83 \\
\hline Maximu & esponseף & $12 \cdot 5$ & $12 \cdot 4$ & $-6 \cdot 2$ & $14 \cdot 7$ & $11 \cdot 3$ & 13.8 \\
\hline Maximu & sponsef & $10 \cdot 6$ & $10 \cdot 2$ & $9 \cdot 6$ & $16 \cdot 3$ & $10 \cdot 9$ & $11 \cdot 7$ \\
\hline Predicte & mum & 153 & 412 & 0.709 & $22 \dagger$ & -6 & $43 \cdot 4$ \\
\hline \multicolumn{8}{|c|}{$\begin{array}{l}\text { * The coefficient was significantly less than zero }(P \leqslant 0.05) \text {. } \\
+ \text { The solution was a saddle point ; all others were a maximum or minimum. } \\
+ \text { Phytin-P was analysed to be } 2.5 \mathrm{~g} / \mathrm{kg} \text { diet. } \\
\$ \text { Incidence of Ca-deficiency-type rickets. } \\
\text { il Incidence of P-deficiency-type rickets. } \\
\text { g/kg diet. }\end{array}$} \\
\hline
\end{tabular}

of $\mathrm{Ca}$ and total $\mathrm{P}$ required for minimum $\mathrm{P}$-deficiency rickets were 7.4 and $8.6 \mathrm{~g} / \mathrm{kg}$ respectively, while in Expt 2 they were 11.3 and $10.9 \mathrm{~g} / \mathrm{kg}$ respectively.

Only one bird was found to have tibial dyschondroplasia in Expt 1. In Expt 2, however, the incidence of tibial dyschondroplasia was somewhat higher, although it was still very low. Since the incidence of tibial dyschondroplasia was so low, this information was omitted from the tables. However, it was noticed that the birds with tibial dyschondroplasia tended to be in the treatments with the best growth.

None of the regression coefficients was significant in the plasma $\mathrm{Ca}$ surface, but the quadratic total $P$ term approached significance $(P<0.07)$ (Table $4 ;$ Fig. 2(G)). Further, the total $P$ main effect was significant. There was no indication that dietary $C$ a had any effect on plasma $\mathrm{Ca}$. There was a quadratic plasma dialysable $\mathrm{P}$ response due to dietary total $\mathrm{P}$ with the highest levels of plasma dialysable $\mathrm{P}$ at intermediate levels of dietary total $\mathrm{P}$ (Table 4; Fig. $2(\mathrm{H})$ ). There was a $\mathrm{Ca} \times$ total $\mathbf{P}$ interaction on plasma dialysable $\mathrm{P}$ indicating 

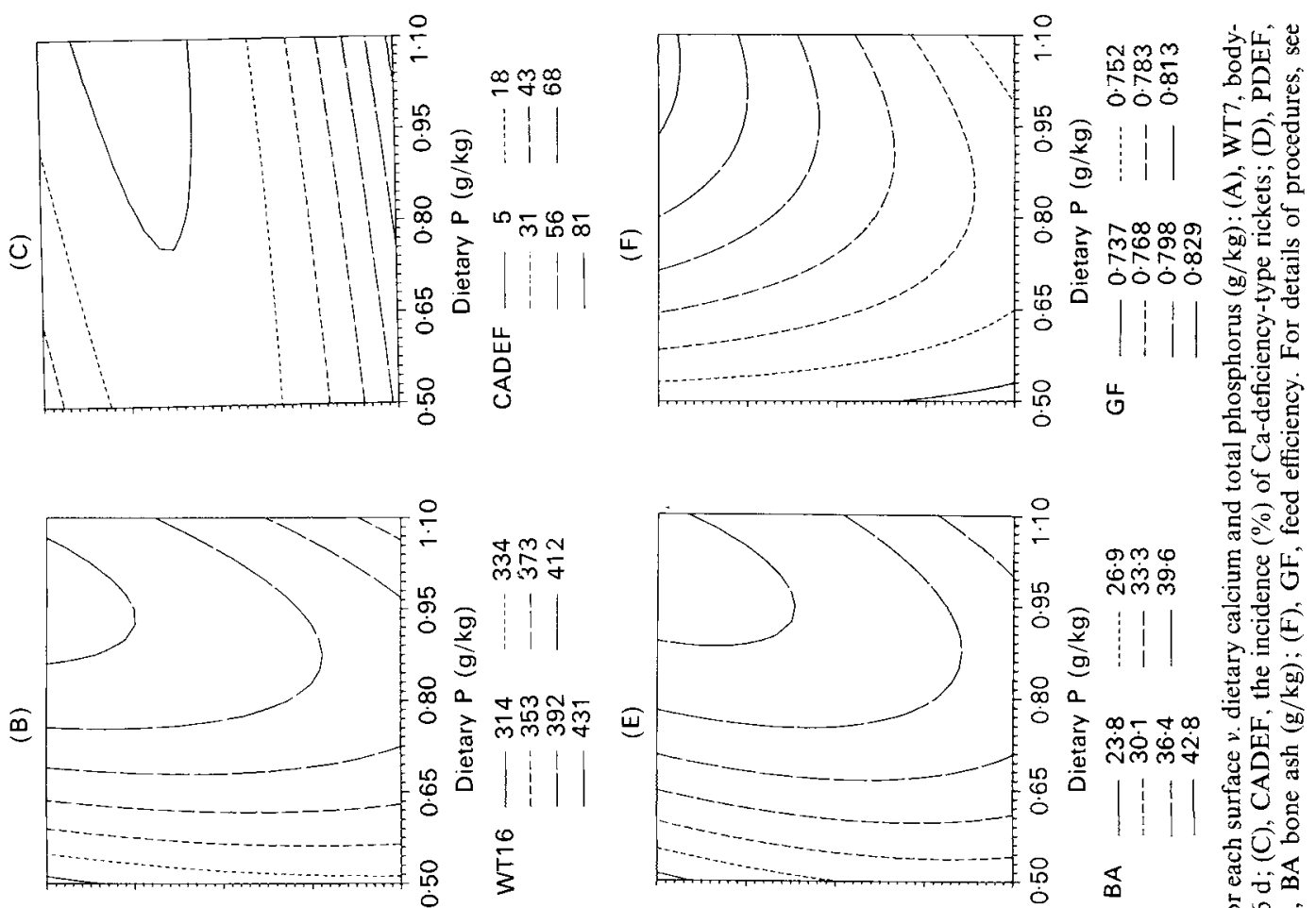

愛

突过

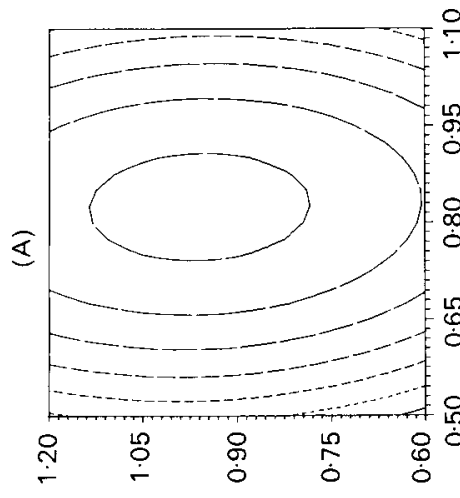

(6x/6) eว kieja!a

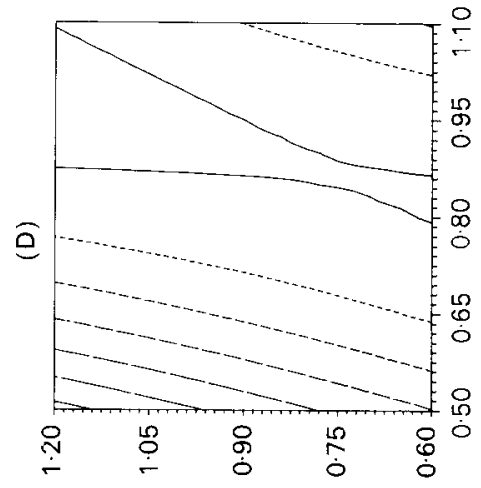

(6r/6) еว Nieta!
害告

厅ु

․․

可商

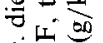

\&

过

至

的

웅

政

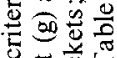

노용

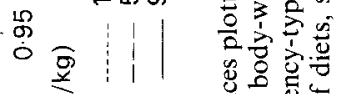

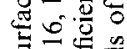

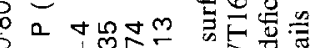
传

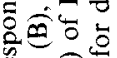

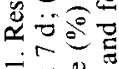

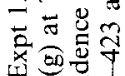
$\therefore$ 동 的要要 


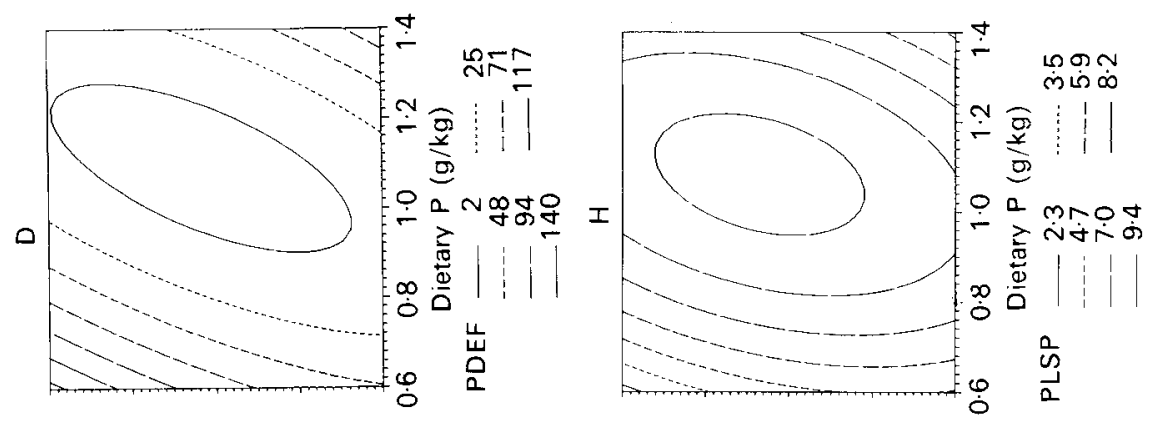

包尊宫

可尊若

के

(30)

表.

年

8

등응

$3 e^{2}$
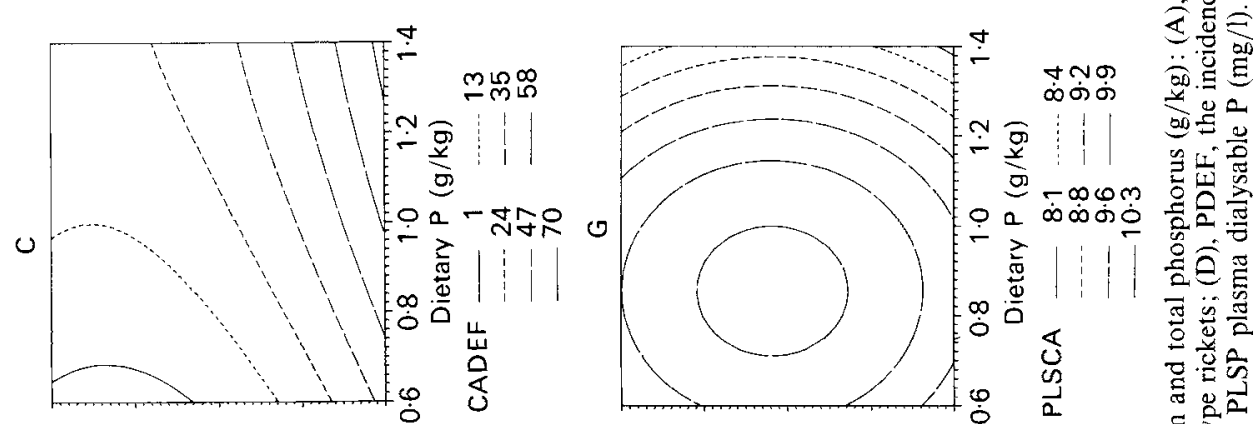

$\leq \frac{\mathrm{g}}{\mathrm{s}}$ 过

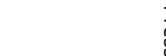
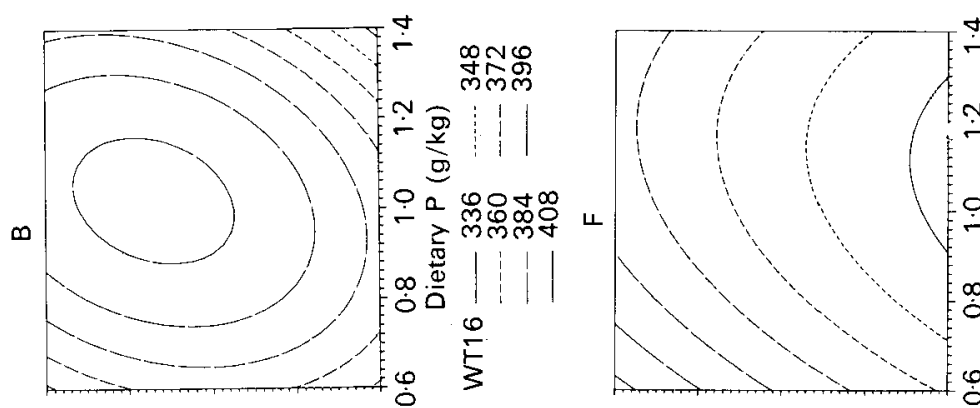

贯定

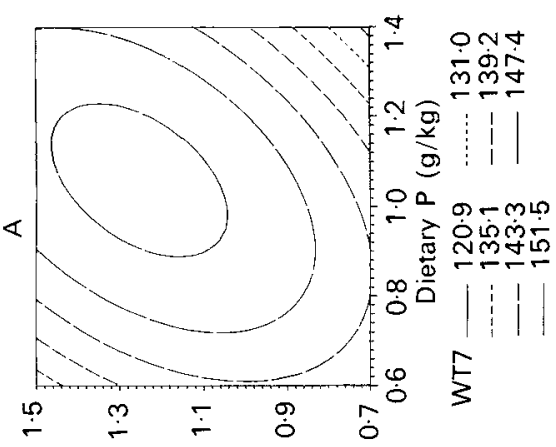

(6y/6) ej Nueja!a

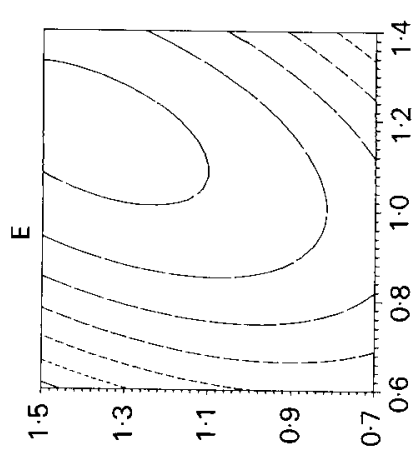

$(6 y / 6)$ eว Mена!

J

运密

要

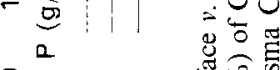

늠

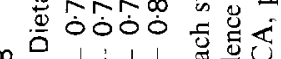

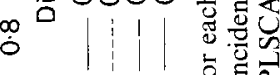

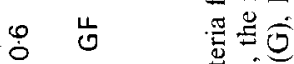

岀苛

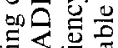

U

五守出

\%

它这

家过它

을

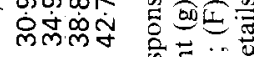

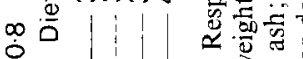

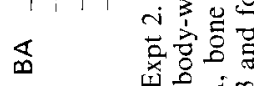

ㄴํำ

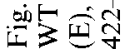


Table 4. Expt 2. The effects of various dietary calcium and phosphorus levels on plasma $C a$ and plasma $P$ of very young turkeys

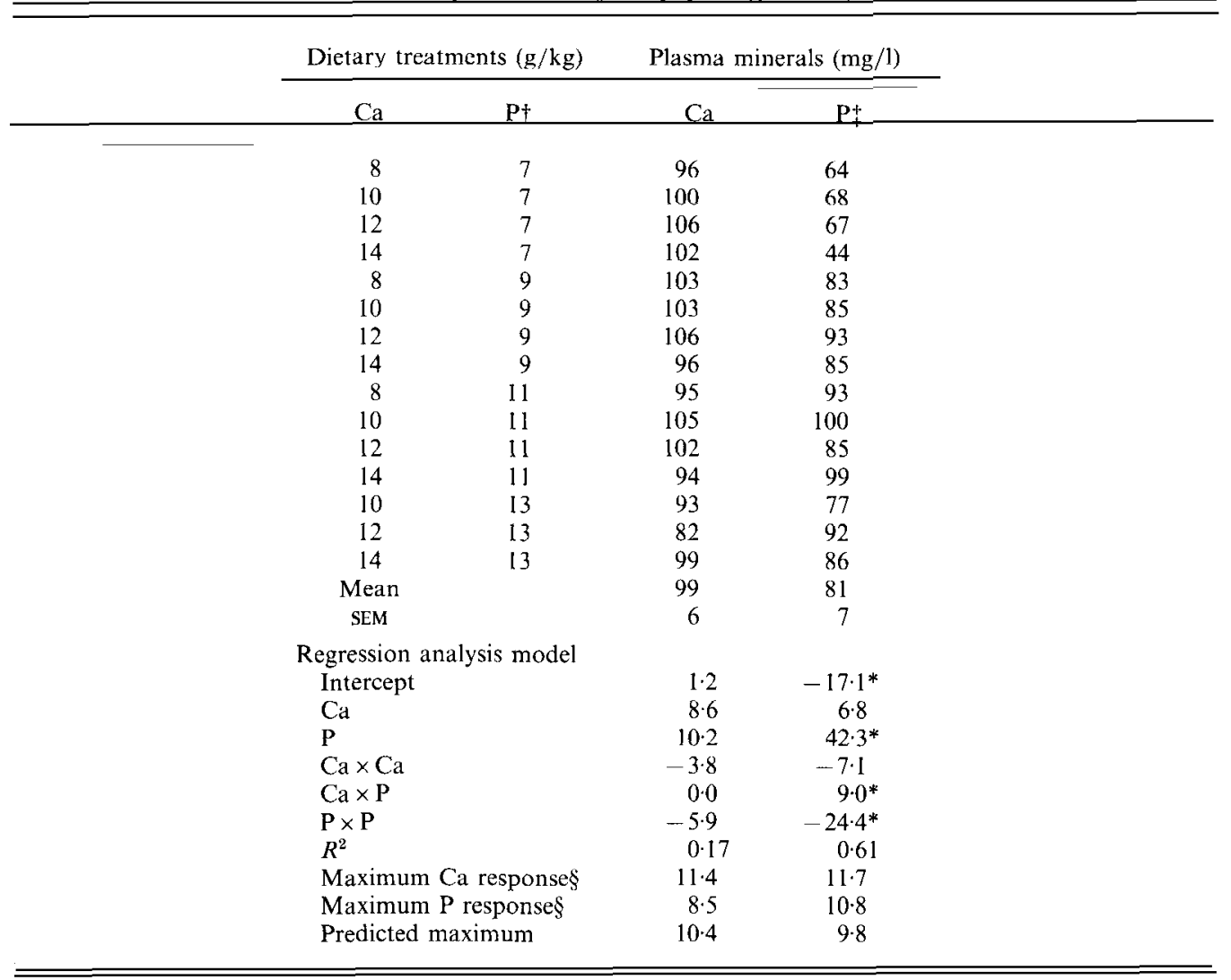

* The coefficient was significantly less than zero $(P \leqslant 0.05)$.

$\dagger$ Phytin-P was analysed to be $2.5 \mathrm{~g} / \mathrm{kg}$ diet.

$\ddagger$ Plasma dialysable phosphorus.

$\S \mathrm{g} / \mathrm{kg}$ diet.

that increasing $\mathrm{Ca}$ levels decrease plasma dialysable $\mathrm{P}$ at low levels of dietary total $\mathrm{P}$. For maximum plasma dialysable $\mathrm{P}$ a Ca level of $11.7 \mathrm{~g} / \mathrm{kg}$ diet and a total $\mathrm{P}$ level of $10.8 \mathrm{~g} / \mathrm{kg}$ diet are required.

There was a quadratic percentage Ca retention response due to dietary total $\mathrm{P}$ at both 7 and $14 \mathrm{~d}$ in Expt 1 and at $7 \mathrm{~d}$ in Expt 2, with the highest percentage retention at intermediate levels of total P (Tables 5 and 6; Figs 3 and 4 (A and D)). At $7 \mathrm{~d}$ in Expt 1, but at no other time in either experiment, there was a quadratic $\mathrm{Ca}$ retention response due to dietary $\mathrm{Ca}$. Also at $7 \mathrm{~d}$ in Expt 1 there was $\mathrm{Ca} \times$ total $\mathrm{P}$ interaction indicating that, at low levels of total $\mathbf{P}$, increasing $\mathrm{Ca}$ levels decrease percentage $\mathrm{Ca}$ retention.

There was a quadratic total $P$ retention response due to dietary total $P$ at both 7 and $14 \mathrm{~d}$ in Expt 1 and at $7 \mathrm{~d}$ in Expt 2; this resulted in the highest percentage retention of total $\mathrm{P}$ varying between low and intermediate levels of dietary total $P$ (Tables 5 and 6; Figs 3 and $4(\mathrm{~B}$ and $\mathrm{E})$ ). There was also a $\mathrm{Ca} \times$ total $\mathrm{P}$ interaction on percentage total $\mathrm{P}$ retention at both 7 and $14 \mathrm{~d}$ in Expt 1, but not in Expt 2, indicating that increasing dietary total $P$ decreases the retention of total $\mathrm{P}$ more dramatically at low levels of dietary $\mathrm{Ca}$. There was 
Table 5. Expt 1. The effects of various dietary calcium and phosphorus levels on the retention of $\mathrm{Ca}, P$, and phytin- $P$

\begin{tabular}{|c|c|c|c|c|c|c|c|}
\hline \multicolumn{2}{|c|}{ Dietary treatments $(\mathrm{g} / \mathrm{kg})$} & \multicolumn{2}{|c|}{ Ca retention $(\%)$} & \multicolumn{2}{|c|}{$\mathrm{P}$ retention $(\%)$} & \multicolumn{2}{|c|}{ Phytin-P retention $(\%)$} \\
\hline $\mathrm{Ca}$ & $\mathrm{P} \ddagger$ & $7 d$ & $14 \mathrm{~d}$ & $7 \mathrm{~d}$ & $14 \mathrm{~d}$ & $7 d$ & $14 \mathrm{~d}$ \\
\hline $9 \cdot 0$ & $5 \cdot 2$ & 29 & 45 & 43 & 49 & 17 & 33 \\
\hline $7 \cdot 0$ & 6.0 & 52 & 62 & 52 & 57 & 29 & 45 \\
\hline $11 \cdot 0$ & $6 \cdot 0$ & 37 & 47 & 48 & 53 & 14 & 28 \\
\hline $6 \cdot 2$ & 80 & 60 & 67 & 45 & 46 & 27 & 46 \\
\hline $9 \cdot 0$ & 8.0 & 64 & 63 & 54 & 51 & 23 & 32 \\
\hline $11 \cdot 8$ & $8 \cdot 0$ & 57 & 56 & 58 & 51 & 16 & 18 \\
\hline $7 \cdot 0$ & $10 \cdot 0$ & 63 & 67 & 41 & 41 & 24 & 31 \\
\hline 11.0 & $10-0$ & 63 & 59 & 50 & 47 & 16 & 20 \\
\hline $9 \cdot 0$ & $10 \cdot 8$ & 65 & 60 & 42 & 41 & 18 & 25 \\
\hline Mean & & 57 & 60 & 50 & 50 & 21 & 31 \\
\hline SEM & & 2 & 2 & 1 & 2 & 2 & 3 \\
\hline \multicolumn{8}{|c|}{ Regression analysis model } \\
\hline Intercer & & $-88 \cdot 4 *$ & $8 \cdot 2$ & $-9 \cdot 6$ & $68 \cdot 6^{*}$ & $41 \cdot 1$ & $87 \cdot 6^{*}$ \\
\hline $\mathrm{Ca}$ & & $24 \cdot 5$ & $-36 \cdot 4$ & $4 \cdot 4$ & $-28 \cdot 1$ & $-50 \cdot 8$ & $-66 \cdot 8$ \\
\hline $\mathrm{P}$ & & $311 \cdot 1^{*}$ & $183 \cdot 0^{*}$ & $144 \cdot 6^{*}$ & 0.6 & $39 \cdot 8$ & $5 \cdot 0$ \\
\hline $\mathrm{Ca} \times \mathrm{Ca}$ & & $-60 \cdot 4^{*}$ & $-14 \cdot 0$ & $-29 \cdot 5^{*}$ & $-8 \cdot 7$ & $-6 \cdot 3$ & $-2 \cdot 3$ \\
\hline $\mathrm{Ca} \times \mathrm{P}$ & & $90 \cdot 8^{*}$ & $45 \cdot 7$ & $79 \cdot 3^{*}$ & $61.7 *$ & $47 \cdot 1$ & 36.0 \\
\hline $\mathbf{P} \times \mathbf{P}$ & & $-210 \cdot 9 *$ & $-124 \cdot 8^{*}$ & $-139 \cdot 2 *$ & $-47 \cdot 9^{*}$ & $-52 \cdot 3^{*}$ & $-36 \cdot 2$ \\
\hline$R^{2}$ & & 0.93 & 0.82 & 0.84 & 0.57 & 0.62 & 0.68 \\
\hline Maximı & esponse§ & $9 \cdot 0$ & -1.5 & $12 \cdot 5$ & $12 \cdot 5$ & 37.9 & $48 \cdot 3$ \\
\hline Maxim! & ponse§ & $9 \cdot 3$ & $7 \cdot 1$ & 8.8 & 8.1 & $20 \cdot 9$ & $24 \cdot 7$ \\
\hline Predicte & num & 68 & 56 & 56 & $51 \dagger$ & $-14 \dagger$ & $-67 \dagger$ \\
\hline
\end{tabular}

a quadratic effect on percentage total $\mathrm{P}$ retention due to Ca at $7 \mathrm{~d}$ in Expt 1, but at no other time in either experiment. In Expt 1 there was a quadratic percentage phytin-P retention response due to dietary total $\mathrm{P}$ at $7 \mathrm{~d}$ but not at $14 \mathrm{~d}$. In Expt 2, however, no such quadratic response was found (Tables 5 and 6; Figs 3 and 4 (C and F)). None of the other coefficients in the regression equations for percentage retention of phytin-P was significant. However, the main effects of both dietary $\mathrm{Ca}$ and total $\mathrm{P}$ were significant at both 7 and $14 \mathrm{~d}$ in both experiments, and the $R^{2}$ terms were high in Expt 1 . There were clearly $\mathrm{Ca}$ and total $\mathrm{P}$ effects on percentage phytin-P retention with the highest retention of phytin-P at the lowest levels of $\mathrm{Ca}$ and $\mathrm{P}$.

\section{DISCUSSION}

The present study indicates that the $\mathrm{Ca}$ and total $\mathrm{P}$ requirements for optimum growth in the very young turkey are 12.5 and $10.0 \mathrm{~g} / \mathrm{kg}$ diet respectively. This conclusion is based primarily on the findings in Expt 2. The predicted optima in Expt 1 for growth are not as reliable since they were beyond the actual levels of $\mathrm{Ca}$ and total $\mathrm{P}$ employed in the experiment. For optimum bone ash, $\mathrm{Ca}$ and total $\mathrm{P}$ must be somewhat higher. However, when the above levels of $\mathrm{Ca}$ and total $\mathrm{P}$ are fed to optimize growth, the predicted bone ash value would be, according to the prediction equation, greater than $410 \mathrm{~g} / \mathrm{kg}$ which is approaching the predicted maximum of 440 and $430 \mathrm{~g} / \mathrm{kg}$ respectively in Expts 1 and 2 . Almost all, if not all, $\mathrm{Ca}$ and $\mathrm{P}$ requirement studies in poultry have used bone ash as one 
Table 6. Expt 2. The effects of various dietary calcium and phosphorus levels on the retention of $\mathrm{Ca}, P$, and phytin- $P$

\begin{tabular}{|c|c|c|c|c|c|c|c|}
\hline \multicolumn{2}{|c|}{ Dietary treatments $(\mathrm{g} / \mathrm{kg})$} & \multicolumn{2}{|c|}{ Ca retention $(\%)$} & \multicolumn{2}{|c|}{$\mathrm{P}$ retention $(\%)$} & \multicolumn{2}{|c|}{ Phytin-P retention $(\%)$} \\
\hline $\mathrm{Ca}$ & $\mathrm{P} \ddagger$ & $7 \mathrm{~d}$ & $14 \mathrm{~d}$ & $7 \mathrm{~d}$ & $14 \mathrm{~d}$ & $7 \mathrm{~d}$ & $14 \mathrm{~d}$ \\
\hline 8 & 7 & 38 & 51 & 57 & 48 & 28 & 23 \\
\hline 10 & 7 & 27 & 49 & 48 & 49 & 17 & 29 \\
\hline 12 & 7 & 28 & 39 & 54 & 50 & 16 & 40 \\
\hline 14 & 7 & 20 & 38 & 55 & 50 & 14 & 18 \\
\hline 8 & 9 & 46 & 46 & 47 & 42 & 24 & 25 \\
\hline 10 & 9 & 45 & 48 & 56 & 44 & 24 & 25 \\
\hline 12 & 9 & 37 & 41 & 54 & 44 & 17 & 14 \\
\hline 14 & 9 & 34 & 42 & 54 & 45 & 5 & 9 \\
\hline 8 & 11 & 47 & 50 & 41 & 34 & 22 & 25 \\
\hline 10 & 11 & 43 & 44 & 44 & 38 & 17 & 8 \\
\hline 12 & 11 & 39 & 42 & 45 & 37 & 13 & 3 \\
\hline 14 & 11 & 40 & 36 & 50 & 40 & 11 & 3 \\
\hline 10 & 13 & 45 & 50 & 36 & 34 & 12 & 12 \\
\hline 12 & 13 & 40 & 43 & 36 & 33 & 5 & 8 \\
\hline 14 & 13 & 36 & 43 & 40 & 36 & 9 & -9 \\
\hline Mean & & 38 & 44 & 48 & 42 & 15 & 16 \\
\hline SEM & & 3 & 3 & 3 & 2 & 4 & 8 \\
\hline \multicolumn{8}{|c|}{ Regression analysis model } \\
\hline Intercep & & $-14 \cdot 3$ & $94 \cdot 3^{*}$ & $44 \cdot 7$ & $79 \cdot 6^{*}$ & $63 \cdot 8$ & $8 \cdot 9$ \\
\hline $\mathrm{Ca}$ & & $-44 \cdot 0$ & $-27 \cdot 1$ & $-21 \cdot 8$ & 1.4 & $-69 \cdot 4$ & $116 \cdot 1$ \\
\hline $\mathrm{P}$ & & $160 \cdot 7 *$ & $-56 \cdot 0$ & $52 \cdot 9$ & $-59 \cdot 8^{*}$ & 17.0 & $-50 \cdot 9$ \\
\hline $\mathrm{Ca} \times \mathrm{Ca}$ & & $2 \cdot 3$ & 0.8 & $3 \cdot 4$ & $-2 \cdot 0$ & 141 & -32.8 \\
\hline $\mathrm{Ca} \times \mathrm{P}$ & & $20 \cdot 4$ & $7 \cdot 4$ & $24 \cdot 1$ & $9 \cdot 0$ & $17 \cdot 2$ & $-72 \cdot 3$ \\
\hline $\mathrm{P} \times \mathrm{P}$ & & $-81 \cdot 2^{*}$ & $25 \cdot 6$ & $-54 \cdot 8^{*}$ & $11 \cdot 5$ & $-24 \cdot 4$ & $48 \cdot 6$ \\
\hline$R^{2}$ & & 0.67 & $0 \cdot 34$ & 0.65 & 0.74 & 0.39 & 0.32 \\
\hline Maximu & esponse§ & $33 \cdot 0$ & $336 \cdot 0$ & $8 \cdot 5$ & $33 \cdot 2$ & 18.5 & 6.6 \\
\hline Maximu & ponse§ & $14 \cdot 0$ & $-37 \cdot 0$ & $6 \cdot 7$ & $13 \cdot 0$ & $10 \cdot 0$ & $10 \cdot 1$ \\
\hline Predicte & num & $25 \cdot 4 t$ & $-256 \cdot 8$ & $53 \cdot 1 \dagger$ & $43.0 t$ & $8 \cdot 1 \dagger$ & $21 \cdot 3 t$ \\
\hline
\end{tabular}

* The coefficient was significantly less than zero $(P \leqslant 0.05)$.

$\uparrow$ The solution was a saddle point; all others were a maximum or minimum.

$\mp$ Phytin-P was analysed to be $2.5 \mathrm{~g} / \mathrm{kg}$ diet.

$\S \mathrm{g} / \mathrm{kg}$ diet.

of the major response criteria. Certainly, bone ash is a very sensitive, predictable, and repeatable response ( $R^{2} 0.94$ and 0.83 in Expts 1 and 2 respectively). But what does optimum bone ash mean in terms of healthy poult development? Further work is necessary to determine the true meaning of early-age bone ash values and how they relate to later performance and leg abnormalities. There was a highly significant correlation between the bone ash response and the $16 \mathrm{~d}$ weight response in Expts 1 and $2(r 0 \cdot 87, P<0 \cdot 001 ; r 0 \cdot 38$, $P<0.003$ respectively). In addition, the levels of $\mathrm{Ca}$ and total $\mathrm{P}$ at which optimum growth was observed resulted in very low incidence of both the $\mathrm{Ca}$ - and $\mathrm{P}$-deficiency lesions. These findings, coupled with the fact that there were no treatment effects on feed efficiency in either experiment, indicate that growth is probably the single best response criterion in determining the $P$ requirements in the young turkey. Since significant responses were obtained to dietary $\mathrm{Ca}$ levels only where $\mathrm{Ca}$-deficiency rickets and bone ash were the criteria, these criteria should be studied with the growth data to determine the $\mathrm{Ca}$ requirement. The turkey may be unusual in this lack of growth response to dietary Ca levels since significant effects on broiler chick growth at $14 \mathrm{~d}$ (Edwards \& Veltmann, 1983) and 

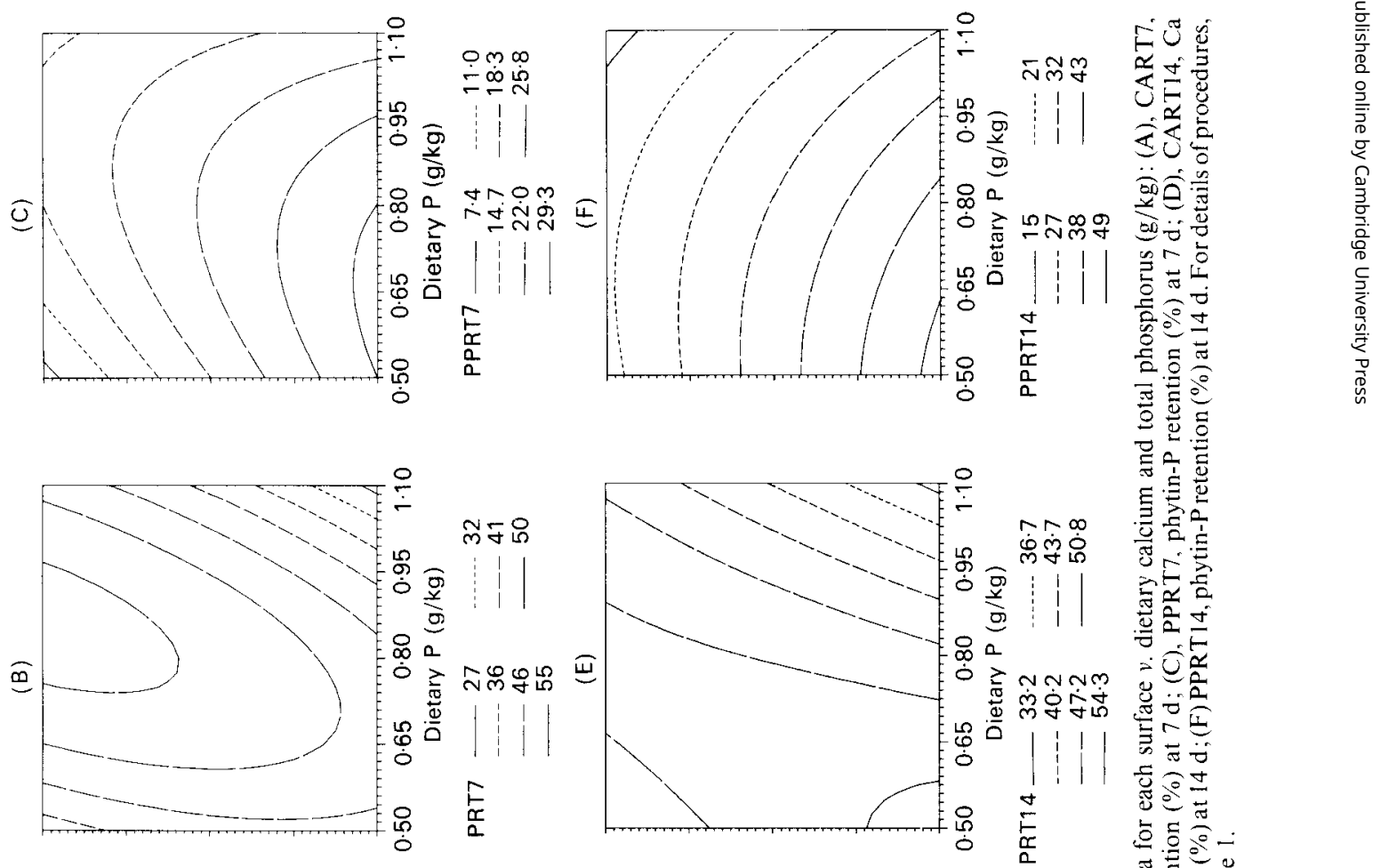

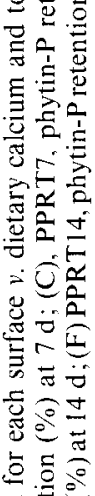

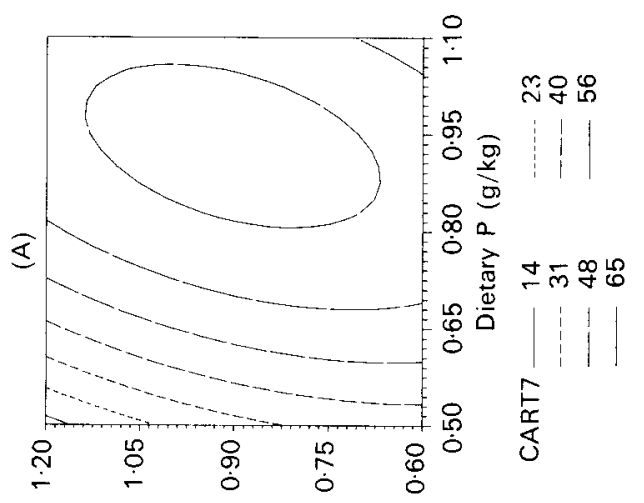

$(6 y / 6)$ еว Клеłə!O

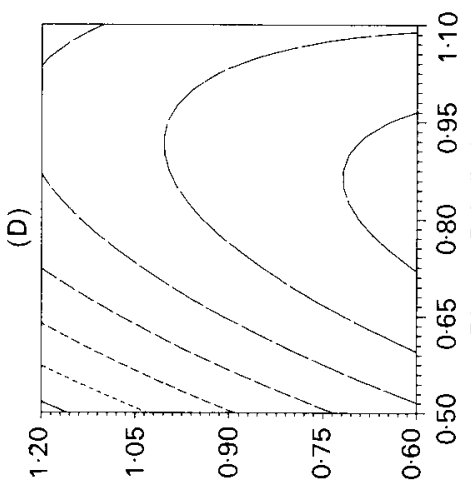

$(6 y / 6)$ eว Niełə!O

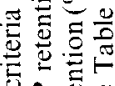

on

ㄷำ व कर क्ञ

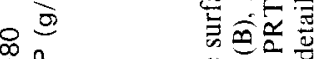

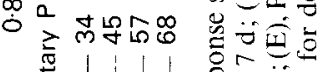

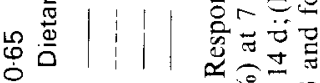
넝

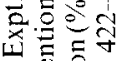

的卷 㔠记 

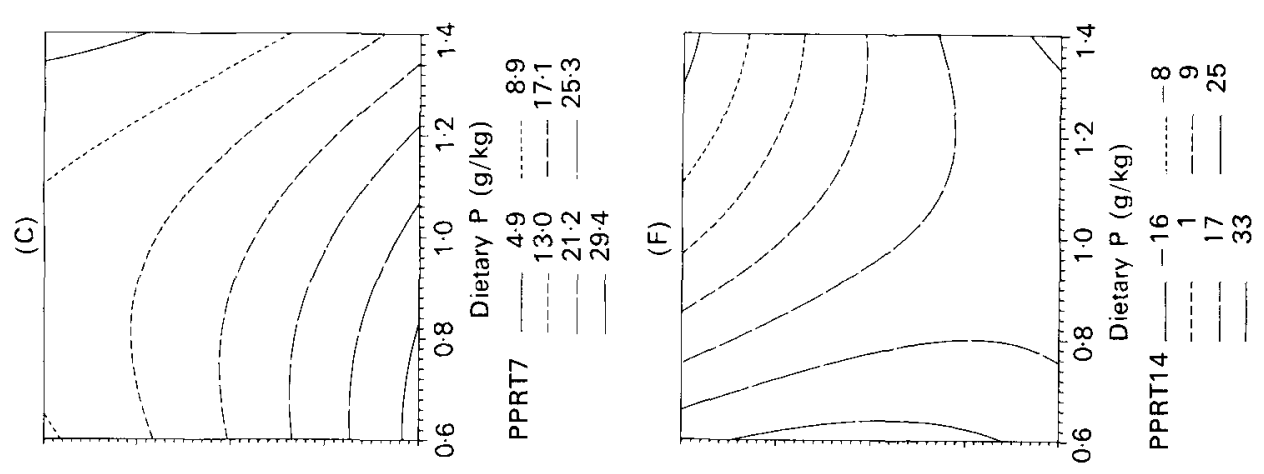

둉ㅇㅇ

毛市

(5)

ड结

$\rightarrow$
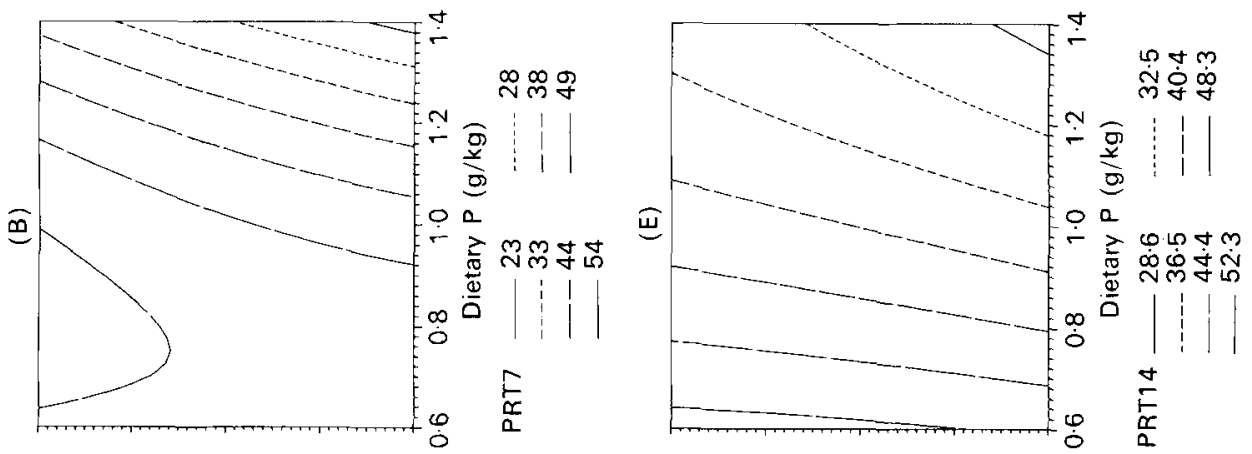

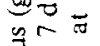

ํํㄹㅇํㅇ

옹연

㱐造

문

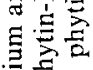

要范

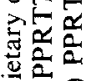

$\therefore \theta$

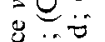

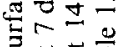

可苟要

氖造

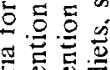

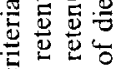
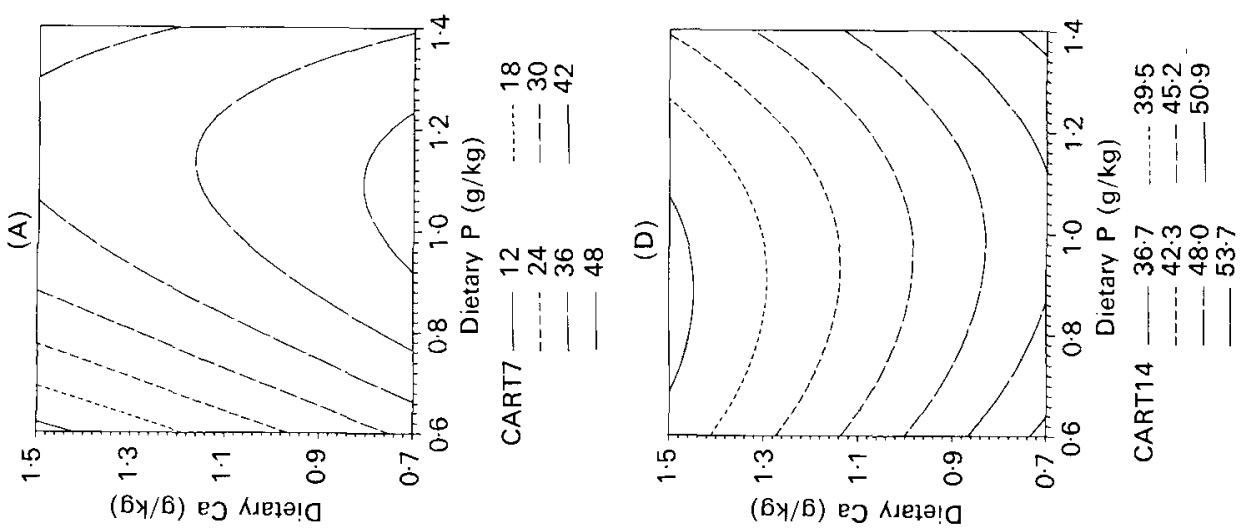

ona

跑要要

怘さ

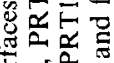

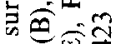

क्ष

등줘

क्षे

유요요

등ㅇㅇ

뙤 동홍

政

诖宓苞 
leghorn and broiler chick growth at $21 \mathrm{~d}$ (Yoshida \& Hoshii, $1982 a, b$ ) were reported in experiments designed for response surface analysis. The use of response surface analysis does not solve the problem of lack of response of specific criteria to levels of a nutrient. It is apparent that the maximum response for a particular criterion has little meaning when none of the coefficients is significant.

Due to the fact that there was only one bird with tibial dyschondroplasia in Expt 1 and a very low incidence in Expt 2, it is very difficult to make any firm conclusions regarding the roles of $\mathrm{Ca}$ and $\mathrm{P}$ in the development of tibial dyschondroplasia in the young turkey. However, it was noted that the treatments with the best growth tended to be treatments where tibial dyschondroplasia was found. This observation supports the hypothesis that tibial dyschondroplasia is closely linked with rapid growth (Wise \& Jennings, 1970; Riddell, 1975; Wise \& Nott, 1975; Freedman et al. 1985). Edwards \& Veltmann (1983) found that a narrow $\mathrm{Ca}$ : total $\mathrm{P}$ ratio would induce the tibial dyschondroplasia lesion in the broiler. We found no such relationship between $\mathrm{Ca}, \mathrm{P}$ and tibial dyschondroplasia in the turkey in the present study. However, it is well established that the tibial dyschondroplasia lesion develops much later in the turkey than in the broiler (Poulos, 1978 a, b). To determine whether there is any relationship between dietary $\mathrm{Ca}$, dietary $\mathrm{P}$ and tibial dyschondroplasia in the turkey, further research using older birds is necessary.

The accuracy of the differential diagnosis of $\mathrm{Ca}$ - and $\mathrm{P}$-deficiency rickets by visual examination is proved by the results and the size of the terms that are significant in the equations for the surface for the different rickets, the $\mathrm{Ca}$ terms being very large and significant for the $\mathrm{Ca}$-deficiency-rickets equation and the $\mathrm{P}$ terms being large and significant for the P-deficiency-rickets equation. The statistical analysis also indicated that $\mathrm{Ca}$ level of the diet significantly influenced the incidence of P-deficiency rickets. In these two experiments only ten birds were diagnosed as having both $\mathrm{Ca}$ - and P-deficiency rickets.

We found an unexpected quadratic response due to dietary total $\mathrm{P}$ in both experiments; increasing the $\mathbf{P}$ level decreased the P-deficiency lesion up to a point beyond which increases in the $P$ level actually increased the incidence of the lesion. In addition, we found a similar quadratic response on plasma dialysable $\mathrm{P}$ but, over the whole range of dietary $\mathrm{P}$ fed, there was a high negative correlation between plasma dialysable $\mathrm{P}$ and the incidence of P-deficiency rickets $(r-0 \cdot 68, P<0 \cdot 001)$. Why would very high levels of dietary $P$ increase the incidence of the P-deficiency lesion and decrease plasma dialysable P? High levels of dietary $\mathrm{P}$ are thought to inhibit $\mathrm{Ca}$ absorption by forming insoluble $\mathrm{Ca}$-phosphorus complexes in the gut (Guyton, 1986). It may be that this increased difficulty in $\mathrm{Ca}$ absorption may result in increased parathyroid hormone secretion in an effort to increase $\mathrm{Ca}$ absorption from the gut to make up for the $\mathrm{Ca}$ deficit. If this is indeed the situation, then the parathyroid hormone would also cause increased renal excretion of $P$ which may exceed the extra $P$ that is being absorbed. The $P$ retention findings support this hypothesis. Further work seems warranted to determine whether parathyroid hormone is responsible for this phenomenon.

We also found a similar Ca deficiency response due to dietary $\mathrm{Ca}$ in Expt 1, but in Expt 2 the quadratic term only approached significance. There was no such significant plasma $\mathrm{Ca}$ response due to dietary $\mathrm{Ca}$, however.

Apparently, many scientists feel that the availability of $\mathrm{P}$ from phytate in plants can be ignored on the assumption that it is completely unavailable (Scott et al. 1982). The National Research Council's (1984) Nutrient Requirements of Poultry has non-phytin-P values in its table of feedstuffs while it discusses the requirements of the animal in terms of 'available' $P$. Apparently, the committee felt that the non-phytin- $P$ and available $P$ are interchangeable terms. The Agricultural Research Council (1975), which presents more values from individual research workers than the National Research Council (1984), gives 
the individual worker's calculation of available phytate- $P$ as an ' available $P$ ' calculation. The present study clearly indicates that phytin- $P$ is indeed retained by the turkey, and the degree to which it is retained varies dramatically with different levels of dietary $\mathrm{Ca}$ and $\mathrm{P}$. Edwards \& Veltmann (1983) and Edwards (1983) found similar responses in the broiler and commercial layer. Thus, there is very strong evidence that phytin-P should not be completely ignored when formulating poultry rations. Further, non-phytin-P and 'available' $P$ are not interchangeable terms; this is our rationale for using total $P$ in the present study as opposed to 'available' or non-phytin-P. Since $15 \%$ phytin-P is retained at the $\mathrm{Ca}$ and total $\mathrm{P}$ levels previously defined as the requirements, one could assume that $15 \%$ of the $2.8 \mathrm{~g}$ dietary phytin- $\mathrm{P} / \mathrm{kg}$ is available to the poult, at these specified requirements. This would mean that the non-phytin-P requirement in the present study is $7.2 \mathrm{~g} / \mathrm{kg}$ diet while the available $P$ requirement is $7.6 \mathrm{~g} / \mathrm{kg}$ diet if available $P$ is defined as non-phytin-P plus retained phytin- $P$. It is conceivable that if the $P$ requirement is determined with one type of ration that is high in phytin-P and the same inorganic $P$ level was used in a different ration with low phytin-P, a marginal $P$ deficiency could result due to the lack of $P$ from phytic acid.

A negative phytin-P retention value was found in Expt 2 when the diet contained $14 \mathrm{~g} \mathrm{Ca}$ and $13 \mathrm{~g} \mathrm{P} / \mathrm{kg}$. Our laboratory has previously reported such negative value for phytin-P retention (Elliot \& Edwards, 1991). The most reasonable explanation is that the extraction procedure does not get $100 \%$ of the phytin-P from the diet but closer to $100 \%$ is obtained from the extraction of the faecal material.

The present study indicates a requirement $(\mathrm{g} / \mathrm{kg}$ diet) for $\mathrm{Ca}$ of 12.5 , total $\mathrm{P} 10.0$, and available $P$ (defined as non-phytin-P plus retained phytin-P) 7.6. The National Research Council $(1971,1977,1984)$ has estimated the minimum $\mathrm{Ca}$ and $\mathrm{P}$ levels for young poults over the last 20 years (expressed as $\mathrm{g} / \mathrm{kg}$ diet) as: $1971: 12,8, \ldots ; 1977: 12,8, \ldots$; 1984: $12 \cdot 5,-, 6$, respectively for total $\mathrm{Ca}$, total $\mathrm{P}$ and available $\mathrm{P}$, where - indicates no value was given.

The National Research Council (1984) considers phytate-P to be unavailable, so their available $\mathrm{P}$ value is non-phytin-P. Therefore, the results of the present study do not indicate any change in $\mathrm{Ca}$ requirement but do indicate that the $\mathrm{P}$ requirement has increased by as much as $25 \%$. During the last part of this 20 -year period (from 1983 to 1991), the average weight of the 18-week-old male and female turkey in the USA increased by 23 and $22 \%$ respectively (Sell, 1991). Perhaps this rapidly growing bird really has a higher $P$ requirement.

There have been problems in previous studies in which there have been very large discrepancies between calculated and analysed values for $\mathrm{Ca}$ and $\mathrm{P}$ in experimental diets (Stephenson et al. 1962). The question could be raised as to whether calculated or analysed values should be used in the analysis of the data. Our calculated and analysed values were relatively close so we decided to use calculated values. For example, the analysed values of the diets used in Expt 1 showed the diets to contain $0.7 \mathrm{~g}$ more $\mathrm{Ca} / \mathrm{kg}$ and $0.5 \mathrm{~g}$ more total $\mathrm{P} / \mathrm{kg}$ than they contained by calculated values. These would both indicate errors in making the requirement estimate of approximately $5 \%$ of the estimated values, which is reasonable for a requirement to be used under an infinite number of variable conditions.

The authors acknowledge support by State and Hatch funds allocated to the Georgia Agricultural Experiment Stations of the University of Georgia.

\section{REFERENCES}

Agricultural Research Council (1975). The Nutrient Requirements of Farm Livestock. No. 1, Poultry Technical Reviews and Summaries, pp. 61-62. London: Agricultural Research Council. 
Association of Official Agricultural Chemists (1955). Official Methods of Analysis, 8th ed. Washington, DC: Association of Official Agricultural Chemists.

Box, G. E. P. \& Wilson, K. B. (1951). On the experimental attainment of optimum conditions. Journal-Royal Statistical Society B13, 1-45.

Brisson, G. J. (1956). On the routine determination of chromic oxide in feces. Canadian Journal of Agricultural Science 36, 210-211.

Choi, J. H. \& Harms, R. H. (1977). Importance of calcium : inorganic phosphorus ratio in diets of starting poults. Nutrition Reports International 15, 437-442.

Common, R. H. (1940). The phytic acid content of some poultry feeding stuffs. Analyst $65,7983$.

Edwards, H. M. Jr (1983). Phosphorus. 1. Effect of breed and strain on the utilization of suboptimal levels of phosphorus in the ration. Poultry Science 62, 77--84.

Edwards, H. M. Jr \& Veltmann, J. R. Jr (1983). The role of calcium and phosphorus in the etiology of tibial dyschondroplasia. Journal of Nutrition 113, 1568-1575.

Elliot, M. A. \& Edwards, H. M. Jr (1991). Some effects of dietary aluminum and silicon on broiler chickens. Poultry Science 70, 1390-1402.

Freedman, B. D., Gay, C. V. \& Leach, R. M. Jr. (1985). Avian tibial dyschondroplasia. II. Biochemical changes. American Journal of Pathology 119, 191-198.

Guyton, A. C. (1986). Medical Physiology, 7th ed., p. 937. Philadelphia, PA: W. B. Saunders and Company.

Hill, J. B. (1955). Automated fluorometric method for determination of serum calcium. Clinical Chemistry 2 , $122-130$.

Long, P. H., Lee, S. R., Rowland, G. N. \& Britton, W. M. (1984a). Experimental rickets in broilers: gross, microscopic, and radiographic lesions. I. Phosphorus deficiency and calcium excess. Avian Diseases 28, $460-474$.

Long, P. L., Lee, S. R., Rowland, G. N. \& Britton, W. M. (1984b). Experimental rickets in broilers: gross, microscopic, and radiographic lesions. II. Calcium deficiency. Avian Diseases 28, 921.932.

Long, P. L., Lee, S. R., Rowland, G. N. \& Britton, W. M. (1984c). Experimental rickets in broilers: gross. microscopic, and radiographic lesions. III. Vitamin D deficiency. Avian Diseases 28, 933-943.

Mussehl, F. E. \& Ackerson, C. W. (1935). Calcium and phosphorus requirements of growing turkeys. Poultry Science 14, 147-151

National Research Council (1971). Nutrient Requirements of Poultry, 6th ed. Washington, DC: National Academy of Sciences.

National Research Council (1977). Nutrient Requirements of Poultry, 7th ed. Washington, DC: National Academy of Sciences.

National Research Council (1984). Nurient Requirements of Poultry, 8th ed. Washington, DC: National Academy of Sciences.

O'Neil, J. V. \& Webb, R. A. (1970). Simultaneous determination of nitrogen, phosphorus and potassium in plant materials by automated methods. Journal of the Science of Food and Agriculture 21, 217-219.

Poulos, P. W. Jr (1978a). Tibial dyschondroplasia in the turkey. A morphologic investigation. Acta Radiologica 358, Suppl., 197-227.

Poulos, P. W. Jr (1978b). Skeletal lesions in the broiler, with special reference to dyschondroplasia (osteochondrosis). Acta Radiologica 358, Suppl., 229-275.

Riddell, C. (1975). Studies on the pathogenesis of tibial dyschondroplasia in chickens. III. Effect of body weight. Avian Diseases 19, 497-505.

Scott, M. L., Nesheim, M. C. \& Young, R. J. (1982). Nutrition of the Chicken, 3rd ed., p. 30I. Ithaca, N.Y.: M. L. Scott and Associates.

Sell, J. L. (1991). Continued improvements in turkey performance in 1990. Turkey World, pp. 12-16. Mount Morris, IL: Watt Publishing Co.

Stephenson, E. L., Rinehart, K. B. \& Bragg, D. B. (1962). Calcium-phosphorus requirements for day-old poults. Poultry Science 41, 1686.

Technicon Instruments Corporation (1969). Technicon AutoAnalyzer Methodology N-3I. Tarrytown, N.Y.: Technicon Instruments Corporation.

Technicon Instruments Corporation (1970). Technicon AutoAnalyzer Methodology N-4C. Tarrytown, N.Y.: Technicon Instruments Corporation.

Wise, D. R. \& Jennings, A. R. (1970). Dyschondroplasia in domestic poultry. Veterinary Record 86, $285-286$.

Wise, D. R. \& Nott, H. (1975). Studies on tibial dyschondroplasia in ducks. Research in Veterinary Science 18 193-197.

Yoshida, M. \& Hoshi, H. (1982a). Re-evaluation of requirement of calcium and available phosphorus for starting egg-type chicks. Japanese Poultry Science 19, $93 \cdot 100$.

Yoshida, M. \& Hoshi, H. (1982b). Re-evaluation of requirement of calcium and available phosphorus for starting meat-type chicks. Japanese Poultry Science 19, 101-109. 


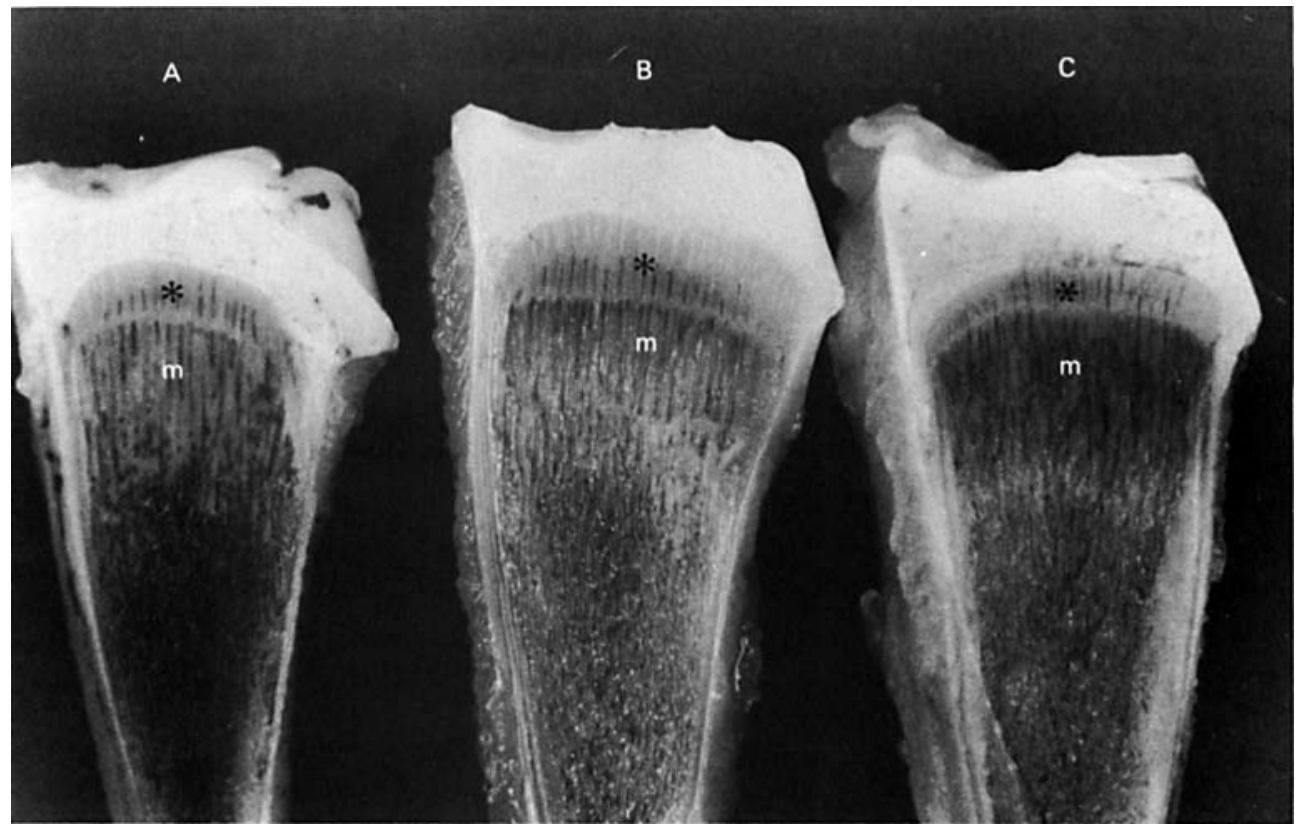

Plate 1. Gross comparison of sagittal sections of the proximal tibiotarsus from 16-d-old poults: (A) control, (B) calcium deficiency, and (C) phosphorus deficiency. The proliferating prehypertrophied zone $\left({ }^{*}\right)$ is increased in size in $B$. The metaphysis $(\mathrm{m})$ is dark and increased in relative length in $\mathrm{C}$. 